\title{
MYC Gene Rearrangement
}

National Cancer Institute

\section{Source}

National Cancer Institute. MYC Gene Rearrangement. NCI Thesaurus. Code C132018.

A molecular abnormality indicating rearrangement of the MYC gene. 